\title{
Necrophagous Insects' Succession on Corpse in African Great Lakes Region
}

\author{
Severin Dushimirimana ${ }^{1 *}$, Barankanira Emmanuel ${ }^{1}$, Gasogo Anastasie $^{2}$ \\ ${ }^{1}$ Ecole Normale Supérieure, Boulevard Mwezi Gisabo, Campus Kigobe, Bujumbura- Burundi \\ ${ }^{2}$ Université du Burundi, Faculté des sciences, département de Biologie
}

\begin{tabular}{|c|c|}
\hline $\begin{array}{c}\text { Article History } \\
\text { Received: } 02.03 .2021 \\
\text { Accepted: } 30.03 .2021 \\
\text { Published: } 21.04 .2021 \\
\\
\text { Journal homepage: } \\
\text { http://www.easpublisher.com }\end{array}$ & $\begin{array}{l}\text { Abstract: Insects are beneficial in many areas such as pollination of plants, } \\
\text { neutralization of pests, control of pest population and production of useful } \\
\text { material including food for humans. In applied entomology, insects are } \\
\text { beneficial for the ecosystem and sustainable agriculture. Biological control } \\
\text { using parasitoids is one of the applications known worldwide. Another very } \\
\text { interesting use is the study of insects associated with a corpse: science known as } \\
\text { forensic entomology. This study was carried out to analyze the succession of } \\
\text { necrophagous insects. The objective is to show their chronology, which could } \\
\text { be used to estimate the post mortem interval (PMI) in Burundi, a country of the } \\
\text { African Great Lakes region where corpses are frequently found in the forests. } \\
\text { Analysis of the results revealed that two species of social insects belonging to } \\
\text { the order of hymenoptera namely Monomoriun pharaonis and Leptothorax } \\
\text { acervorum arrive early on the corpse. These results could be explained in three } \\
\text { ways: the chemical reception of social insects of the order hymenoptera } \\
\text { illustrated by the smell of gases from the degradation and decomposition of the } \\
\text { corpse, but also behavior and communication of social insects. } \\
\text { Keywords: Necrophagous, dead body, forensic entomology, great lakes region. }\end{array}$ \\
\hline opyright (C) 2021 The Author(s): Thi & $\begin{array}{l}\text { en-access article distributed under the terms of the Creative Commons Attribution } 4.0 \text { International } \\
\text { cted use, distribution, and reproduction in any medium for non-commercial use provided the original }\end{array}$ \\
\hline
\end{tabular}

\section{INTRODUCTION}

Insects are helpful for many positive actions such as pollinating plants, neutralizing pest species, population control, producing useful things and food for human. In applied entomology there are many fields which are beneficial to the ecosystem and sustainable agriculture. Biological control using parasitoids is known throughout the world. In research, there is many interesting field where insects are used to understand ecosystems functioning or to improve human health. Very interesting is the study of insects associated with a corpse. The discovery of a corpse raises questions about what happened. People need answers on many questions: the origin of the victim, the date and time of death. For some countries with modern laboratories, theses informations can be obtained by using several methods, among them the analysis and characterization of corpse [1].

In many African countries like Burundi, laboratories materials for evaluating a corpse are not available. There is therefore obvious need for alternative methods for analyzing corpses. After death, the body becomes a favorite biotope of predators. The corpse is colonized by voracious insects and other carnivorous animals. All of these species share the same goal: to take advantage of this resource as early as possible, to develop and grow their generations as much as possible. In this competition, insects are often the fastest and the most effective [1].

The role of these insects is essential in the process of corpse decomposition. For those insects, the corpse is a source of food, a place of laying eggs, or an ideal biotope for generations [2,3]. The succession of insects colonizing a corpse have been interested many researchers [4-7]. In forensic entomology, insects are used to analyze the corpse and to explain what has been happen during the crime [8]. The study of their succession on corpse makes possible to calculate the Post-Mortem Interval (PMI) in criminal cases [8-11].

Forensic entomology is not limited to the estimation of Post-Mortem Interval in case of suspicious death only. In entomoxicology, insects collected at the crime place or on corpse can also help to determine the causes of death in cases of ingesting drugs or poisons, toxins and alcohol [10-12]. 
The main objective of this study is to show main taxa associated with corpse and they arrival chronology which could be used to know the PMI in African great lakes region where cadavers are usually found in forest.

We carry out a systematic analysis of necrophagous insects from the Kirimiro region of Burundi in order to contribute to the knowledge of tropical necrophagous insects and their arrival on corpse.

\section{Material ANd Method Study Area}

The study was carried out in Kirimiro Natural Region of Burundi known to have the same ecological conditions. Two sites Nyabikere and Mutaho have been chosen in this study, we made traps with mice killed. To protect the bodies of predators, wooden sticks have been attached on mice with a piece of metal with the holes which allowed insects to pass. Each piece of metal was attached to wooden rods to protect mice against other carnivores.

At Mutaho, we have installed our traps in eucalyptus plantation located at 850 meters from Mutaho market and 100 meters from the National Road 15. The Nyabikere site, traps were installed north of the Nyabikere commune bureau in eucalyptus plantation located at 600 meters. The experimentation was carried out in 14 days.

\section{Insect collecting and identification methods}

Traps were observed at 24,48,72,96,120,144 hours after death of mice. To catch flying insects, we used an entomological net. For other insects, a racket made of a metal was used. Identification of the insects was made by using insect body characteristics like wing structure, mouth structure etc; and some forensic entomology books [2-13]. The necrophagous insects were kept in $70 \%$ alcohol. Larvaes was not concerned.

\section{Data Analysis}

In this study, individuals identified were grouped into systematic taxa to show numerical importance. Quantitative data was calculated using two parameters: specific richness (SR) and Relative Abundance (RA). Specific Richness (SR) represents the number of species found on mice corpse during the study period. Relative Abundance (RA) is a percentage of individuals belong to a specie (ni) compared to the total number of individuals $(\mathrm{N})$ for all species found on mice corpse.

After identification, the evolution of main taxa was followed and necrophagous insects' succession on mice corpse during 6 days was determined.

\section{RESUlTS}

\section{Necrophagous insects identified at Mutaho}

In this study, during 14 days of observation, we collected a total of 937 individuals belongs to 3 families: Formicidae, Calliphoridae, muscidae. All individuals belong to 10 species of Diptera and Hymenoptera. The results show four species which are more representative: Monomorium pharaonis, Leptothorax acervorum, Calliphora vomitoria, Calliphora vicina (Table-1).

Table-1: Checklist of Necrophagous insects identified at Mutaho

\begin{tabular}{|l|l|l|l|l|}
\hline Order & Families & Genus & Species & Number of individuals \\
\hline Hymenoptera & Formicidae & Leptothorax & Leptothorax acervorum & 213 \\
\hline Hymenoptera & Formicidae & Monomorium & Monomorium pharaonis & 302 \\
\hline Hymenoptera & Formicidae & Aphaenogaster & Aphaenogaster senilis & 13 \\
\hline Diptera & Calliphoridae & Calliphora & Calliphora vicina & 165 \\
\hline Diptera & Calliphoridae & Calliphora & Calliphora vomitoria & 187 \\
\hline Diptera & Calliphoridae & Sarcophaga & Sarcophaga carnaria & 8 \\
\hline Diptera & Muscidae & Musca & Musca domestica & 27 \\
\hline Diptera & Calliphoridae & Luculia & Luculia Caesar & 6 \\
\hline Diptera & Calliphoridae & Luculia & Lucilia sericata & 11 \\
\hline Diptera & Muscidae & Muscina & Muscina stabulans & 5 \\
\hline $\mathbf{2}$ & $\mathbf{3}$ & $\mathbf{8}$ & $\mathbf{1 0}$ & $\mathbf{9 3 7}$ \\
\hline
\end{tabular}

\section{Necrophagous insects identified at Nyabikere}

At Nyabikere, during 14 days of observation, we collected a total of 1473 individuals belongs to 7 families: Formicidae, Calliphoridae, muscidae, Sarcophagidae, Silphidae, Dermestidae, Piophilidae. All individuals belong to 17 species of Diptera,
Hymenoptera and coleoptera. With those results, we identified also four species which are more representative: Monomorium pharaonis, Leptothorax acervorum, Calliphora vomitoria, Calliphora vicina (Table-2). 
Table-2: Checklist of Necrophagous insects identified at Nyabikere

\begin{tabular}{|l|l|l|l|l|}
\hline Order & Families & Genus & Species & Number of individuals \\
\hline Hymenoptera & Formicidae & Aphaenogaster & Aphaenogaster senilis & 13 \\
\hline Hymenoptera & Formicidae & Leptothorax & Leptothorax acervorum & 452 \\
\hline Hymenoptera & Formicidae & Monomorium & Monomorium pharaonis & 371 \\
\hline Diptera & Muscidae & Musca & Musca domestica & 15 \\
\hline Diptera & Muscidae & Muscina & Muscina stabulans & 6 \\
\hline Diptera & Calliphoridae & Calliphora & Calliphora vicina & 112 \\
\hline Diptera & Calliphoridae & Calliphora & Calliphora vomitoria & 341 \\
\hline Diptera & Calliphoridae & Lucilia & Lucilia caesar & 67 \\
\hline Diptera & Calliphoridae & Lucilia & Lucilia illustris & 41 \\
\hline Diptera & Calliphoridae & Lucilia & Lucilia sericata & 13 \\
\hline Diptera & Sarcophagidae & Sarcophaga & Sarcophaga carnaria & 6 \\
\hline Coleoptera & Silphidae & Silpha & Silpha obscura & 5 \\
\hline Coleoptera & Dermestidae & Dermestes & Dermestes maculatus & 4 \\
\hline Coleoptera & Dermestidae & Dermestes & Dermestes peruvianus & 12 \\
\hline Diptera & Calliphoridae & Sarcophaga & Sarcophaga argyrostoma & 9 \\
\hline Diptera & Calliphoridae & Chrysomya & Chrysomya albiceps & 4 \\
\hline Coleoptera & Piophilidae & Piophila & Piophila casei & 2 \\
\hline $\mathbf{3}$ & 7 & $\mathbf{1 2}$ & $\mathbf{1 7}$ & $\mathbf{1 4 7 3}$ \\
\hline
\end{tabular}

\section{Necrophagous taxa succession on mice corpse}

In six days of analyzing the mice corpse, we found that three orders: Hymenoptera, Diptera and Coleoptera were constantly present. The results show that insects belonging to the order Hymenoptera arrive massively on the corpse and become almost the only order present in 24 hours with a relative abundance of
93.55\% (Figure-1). We observed a regressive evolution of the insects belongs to this order after 24 hours.

In contrast, the Diptera insects are not abundant $(6.45 \%)$ on corpse in decomposition during first hours but have a progress evolution to become dominant (81.3\%) after six days (144 hours) (Figure-1). We found that Coleoptera insect remain less dominant than Hymenoptera and Diptera.

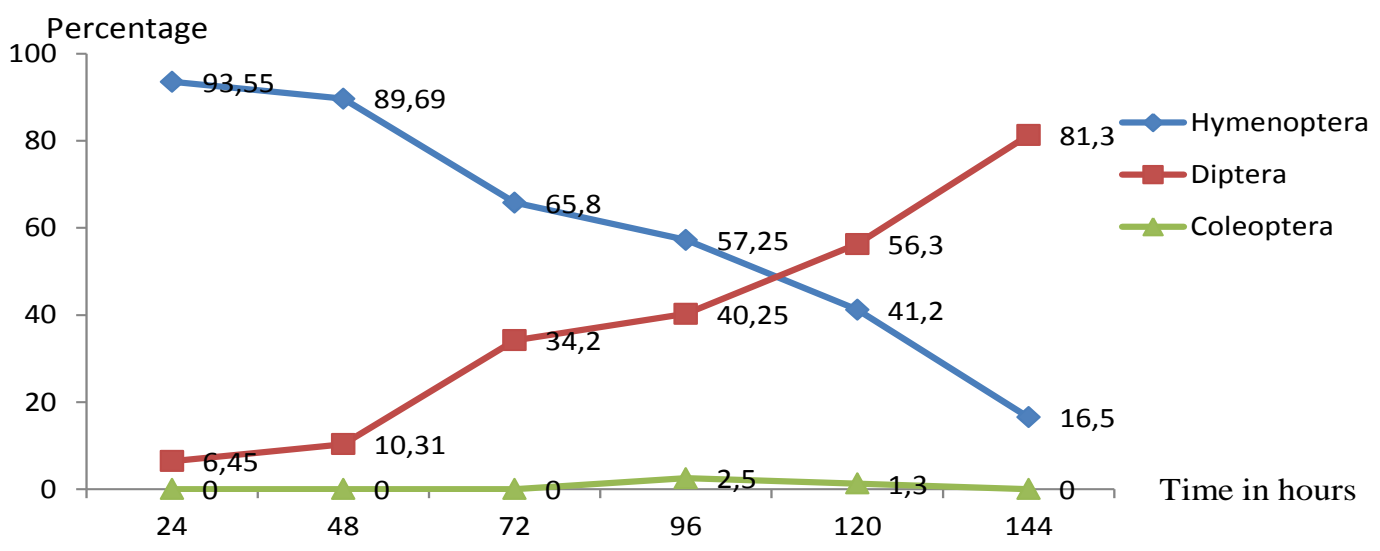

Fig-1: Evolution of main orders of necrophagous insects on corpse

\section{Evolution of major species of necrophagous insects} on corpse

In this study, four species: Monomoriun pharaonis, Leptothorax acervorum , Calliphora vomitoria and Calliphora vicina have catched our attention. Our results show that Monomoriun pharaonis and Leptothorax acervorum arrive massively during the first 24 hours and are dominant with 45.2 and $43.5 \%$ respectively and then their evolution regress to become less represented after 144 hours. We found that two species Calliphora vomitoria and Calliphora vicina are not dominant in the first 24 hours but increase rapidly to become dominant in 72 hours (Figure-2). 


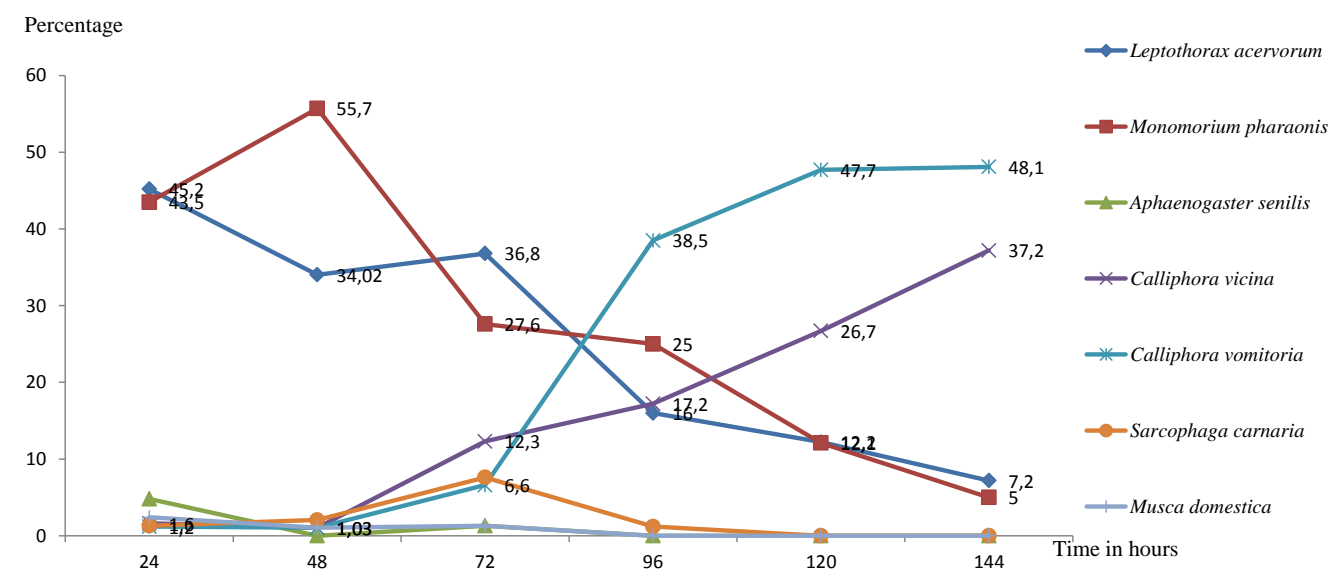

Fig-2: Evolution of major species of necrophagous insects on corpse

\section{DISCUSSION}

The study investigated the succession of necrophagous insects on mice corpse; small Mammalia which belong to the same class with human. The goal was to show main taxa associated with corpse and they arrival chronology which could be used to know the PMI in African great lakes region where cadavers are usually found in forest.

The findings of the study revealed that two Hymenopterous species: Monomoriun pharaonis, Leptothorax acervorum, arrive early during the first hours on the corpse. The meaning of this very early arrival of those species could be explained in three aspects: (1) chemical communication of insects illustrated by gases from the breakdown of corpse (2) social insect behavior (3) competition [13].

Indeed, gases are associated with stages of post mortem change. In this research, Monomoriun pharaonis and Leptothorax acervorum arrive during the fresh stage which is associated with bacterial activity and gases production during the corpse decomposition. Anatomic studies of Monomoriun pharaonis have showed specific adaptation with an increased size and complexity of the organs that are related to olfaction which help those hymenoptera in reception of gases produced by corpse [13]. Those odors emanating from corpse are interpreted as a ready food. Researchs have shown also that Hymenoptera species are first colonizers because of their feeding preferency on tissue of corpse and Monomoriun pharaonis has been reported to be a serious predator in African tropical zone [14].

The results are explained also by behavior. Indeed, during colony relocation, site selection involves exploration and assessment of local resource availability followed by colony movement on the basis of a collective decision making process $[15,16]$. Social insect colony movement explain the rapidly abundance of Monomoriun pharaonis and Leptothorax acervorum on mice corpse.
The results show a decrease in evolution where Monomoriun pharaonis and Leptothorax acervorum species disappears whereas Calliphora vomitoria and Calliphora vicina arrive in abundance on corpse. The main explanation is competition between Diptera and Hymenoptera species. Indeed, Diptera species: Calliphora vomitoria and Calliphora vicina are attracted to the corpse by the smell of the decomposition and putrefaction gases, which includes ammoniacal fermentation of the corpse [16]. In presence of Hymenoptera, the competition is gained by Diptera species which consider also corpse as an ideal laying place to be protected.

\section{REFERENCES}

1. Charabidze, D. (2008). Étude de la biologie des insectes nécrophages et application à l'expertise en entomologie médico-légale. Sciences du Vivant [qbio]. Université du Droit et de la Santé - Lille II.

2. Dorothy, E. G. (2007). Forensic Entomology: An Introduction. John Wiley \& Sons Ltd, The Atrium, Southern Gate, Chichester, West Sussex PO19 8SQ, England.

3. Derkeirsschieter J., Verheggen F., Hubrecht F., Gohy M., Lognay G., \& Haubruge E. (2007). Study of the odours emitted by decaying pig's carcasses (Sus domesticus L.) and postmortem colonisation by necrophagous insects. Journées d'études DVI 2010. Bruxelles, Belgique. 8-9 novembre 2007.

4. Megnin, P. (1894). La faune de cadavres. Application de l'Entomologie à la Médicine Légale. Encyclopédie scientifique des aides Mémoire. Masson, Paris: Gauthier - Villars.

5. de N. Hough, G. (1897). The fauna of dead bodies, with especial reference to Diptera. The British Medical Journal, 1853-1854.

6. Easton, A. M., \& Smith, K. G. V. (1970). The entomology of the cadaver. Medicine, Science and the Law. 10:208-215.

7. Rodriguez, W. C., \& Bass, W. M. (1983). Insect activity and its relationship to decay rates in human 
cadavers in Eastern Tennessee. Journal of Forensic Sciences. 28(2):423-432

8. Goff, M. L. (1993). Estimation of post mortem interval using arthropod development and successional patterns. Forensic Science Review. 5(2):81-94.

9. Jens, A., Carlo, P. C., Lee, G., \& Martin, G. (2010). Current Concepts in Forensic Entomology. Springer Science Business Media B.V. 2010.

10. Jason, H. (2009). Forensic Entomology: The Utility of Arthropods in Legal Investigations, Second Edition. Byrd CRC Press.

11. Wyss, C., \& Cherix, D. (2006). Traité d'entomologie forensique. Dater le décès en entomologie medico-legale, 49:239-252.

12. Bourel, B., Tournel, G., Hédouin, V., Goff, M. L., \& Gosset, D. (2001). Determination of drug levels in two species of necrophagous Coleoptera reared on substrates containing morphine. Journal of Forensic Science, 46(3), 600-603.
13. Chin, H. C., Marwi, M. A., Hashim, R., Abdullah, N. A., Dhang, C. C., Jeffery, J., ... \& Omar, B. (2009). Ants (Hymenoptera: Formicidae) associated with pig carcasses in Malaysia. Tropical Biomedicine, 26(1), 106-109.

14. Anastassios, L. (1979). Aspects of chemical communication in pharaoh's ant, Monomorium pharaonis). Thesis, university of Southampton.

15. Hamilton, W. D. (1972). Altruism and Related Phenomena, Mainly in Social Insects. Annual Review of Ecology and Systematics, 3(1972), 193232.

16. López- Riquelme, G. O., Malo, E. A., CruzLópez, L. E. O. P. O. L. D. O., \& Fanjul- Moles, M. L. (2006). Antennal olfactory sensitivity in response to task- related odours of three castes of the ant Atta mexicana (hymenoptera: formicidae). Physiological Entomology, 31(4), 353-360.

Cite This Article: Severin Dushimirimana et al (2021). Necrophagous Insects' Succession on Corpse in African Great Lakes Region. East African Scholars J Agri Life Sci, 4(4), 96-100. 